\title{
Peculiarities of Tertiary petroleum systems evolution under prograding shelf environment on the continental margin of the East Siberian Sea
}

\author{
R. N. Mustaev ${ }^{1}$ (D) E. A. Lavrenova ${ }^{1}$ 'V. Yu. Kerimov ${ }^{1}$ R. A. Mamedov ${ }^{1}$
}

Received: 24 June 2021 / Accepted: 27 August 2021 / Published online: 4 September 2021

(c) The Author(s) 2021

\begin{abstract}
The upper part of the sedimentary cover within the East Siberian Sea shelf comprises Cenozoic clinoform deposits, which accumulated in passive continental margin settings. In the Eastern Arctic, the productivity of clinoform deposits has been proved on the Alaska North Slope and in the Beaufort-Mackenzie Basin. Considering that Cenozoic clinoform deposits are widely represented in the Russian part of the Eastern Arctic, they undoubtedly attract considerable interest from the standpoint of hydrocarbons prospecting. However, despite increasingly closer attention to this interval of the sedimentary section, it is still poorly understood due to its complicated geology. The lack of drilled wells in the region imposes a considerable limitation on an understanding of sedimentary basins development. In this situation, geophysical data become the primary source of information for building geologic models in the Russian sector of the Eastern Arctic. An assessment of hypothetical Cenozoic petroleum systems of the East Siberian Sea is the main objective of this paper. It is to be said research performed under high uncertainty of input data. The results obtained from basin analysis and numerical modeling indicate the possibility that an active petroleum system may exist in the Cenozoic sedimentary wedge of the East Siberian Sea. The outlook for the clinoform complex largely depends on the source rock maturity, i.e., higher prospects should be expected in areas where the prograding wedge has maximum thickness. Considering all factors (reservoir quality prediction, proximity to a hydrocarbon kitchen, timing), the Eocene-Oligocene part of the sedimentary section appears to offer the greatest promise within the study area. Here, predominantly oil accumulations may be expected at a depth of $2.5-3.5 \mathrm{~km}$ below sea bottom.
\end{abstract}

Keywords Petroleum systems $\cdot$ Continental margin $\cdot$ East Siberian Sea $\cdot$ Hydrocarbons $\cdot$ Sedimentary cover $\cdot$ Clinoform complex

\section{Introduction}

The upper part of the sedimentary cover within the East Siberian Sea shelf comprises Cenozoic clinoform deposits, which accumulated in passive continental margin settings. Particular aspects of the formation of such geologic features are generally conducive to the development of the essential petroleum systems elements (Patrunoa and Helland-Hansenb 2018). They are of great interest from the standpoint of hydrocarbons prospecting, since prolific delta basins are well known around the world.

R. N. Mustaev

r.mustaev@mail.ru

$1 \quad$ Sergo Ordzhonikidze Russian State University for Geological Prospecting, Moscow, Russian Federation
In the eastern Arctic, the productivity of clinoform deposits has been proved on the Alaska North Slope and in the Beaufort-Mackenzie Basin (Fig. 1).

On the Alaska North Slope, the Brookian clinoform complex of the Colville Basin comprises Upper Cretaceous deposits (the Nanushuk and Torok formations). Although it has been well studied by drilling, only one minor oil field was discovered in this complex up until 2015. However, several large discoveries in 2015-2017 (Pikka-Horseshoe, Willow, Smith Bay) have shown that the potential of Cretaceous clinoform deposits is substantially higher than previously expected (Houseknecht 2017,2019a, b). Most discovered fields are confined to the topset beds of the Nanushuk Formation, the only exception being the Smith Bay field discovered in the turbidites of the Torok Formation. Subsidence and intense sediment accumulation in the Colville 


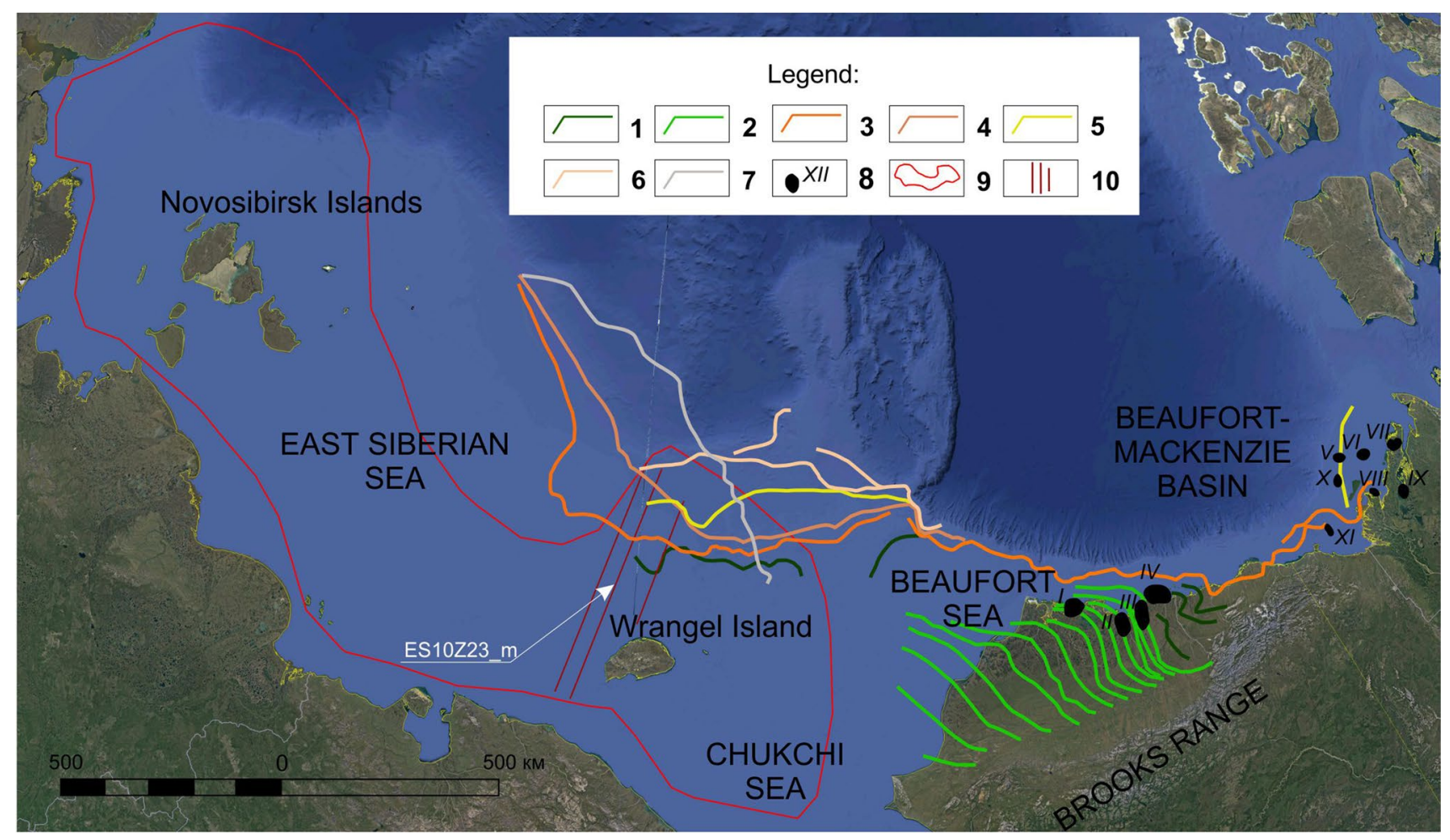

Fig. 1 Overview map of the study area in the Eastern Arctic vicinity, showing the location of topset-slope rollovers (adopted from Skaryatin et al. 2020), and main discoveries in the Upper Cretaceous and Tertiary clinoform sequences (adopted from Morrell et al. 1995; Chmielowski et al. 2018; Skaryatin et al. 2020). Topset-slope

Basin came to a halt in the Cenozoic, and the region has experienced several phases of uplift (O'Sullivan et al. 1997).

Unlike the Alaska North Slope, significant volumes of sediments have accumulated in the Beaufort-Mackenzie Basin during the Cenozoic. The clinoforms of the Beaufort-Mackenzie Basin have been forming in a prograding delta environment since the latest Cretaceous until the present day. The available drilling data show that although all sandstones in the Cenozoic interval of the section exhibit good reservoir properties, only Eocene to Early Miocene strata are productive (Morrell et al. 1995). They host oil, gas, and oil-and-gas accumulations. More than 40 onshore and offshore discoveries have been made in the Tertiary sediments of the Beaufort-Mackenzie Basin. However, the basin's potential is far from being exhausted. Among the largest gas accumulations are the Taglu (1971), Amauligak (1983), and lssungnak (1980) fields. The following oil fields on the shelf are known for their oil volumes: Amauligak (1983), Adlartok (1985), and Kopanoar (1976) (Morrell et al. 1995).

Considering that Cenozoic clinoform deposits are widely represented in the Russian part of the Eastern Arctic, they undoubtedly attract considerable interest from the standpoint rollovers: $1-\mathrm{K}_{1 \mathrm{a}-\mathrm{al}}, 2-\mathrm{K}_{2}-\mathrm{Pg}_{1}{ }^{1}, 3-\mathrm{Pg}_{1}{ }^{2}-\mathrm{Pg}_{2}{ }^{2}, 4-\mathrm{Pg}_{2}{ }^{2}-\mathrm{Pg}_{3} 5-\mathrm{N}_{1}{ }^{1-2}$, 6- $\mathrm{N}_{1}{ }^{2-3}, 7-\mathrm{N}_{2}-\mathrm{Q}$. 8-Main discoveries: I- Smith Bay, II-Willow, III-Pikka-Horseshoe, IV-Ugnu, V-Kopanoar, VI-Amauligak, VII-Atkinson point, VIII-Taglu, IX - Parsons Lake $X$-lssungnak $X I$-Adlartok. 9-regional model extent, 10 - seismic lines

of hydrocarbons prospecting. However, despite increasingly closer attention to this interval of the sedimentary section, it is still poorly understood due to its intricate geology, and its hydrocarbon potential remains underestimated (Lavrenova et al. 2019; Kerimov et al. 2018a,b,c, 2019; Mustaev et al. 2016). The lack of drilled wells in the region imposes a considerable limitation on an understanding of sedimentary basins development. In this situation, geophysical data become the primary source of information for building geologic models in the Russian sector of the eastern Arctic.

An assessment of hypothetical Cenozoic petroleum systems of the East Siberian Sea is the main objective of this paper. It is to be said research performed using input data with high uncertainty.

\section{Geological settings}

The absence of wells in the East Siberian Sea makes dating seismic horizons an extremely complicated task with ambiguous results. Most researchers attempt to tie these horizons to wells drilled in the US sector of the Chukchi Sea. Considering that these wells and the Russian sector of the Eastern 
Arctic are separated by complicated tectonic zones, this tie is fairly tentative (Ilhan et al. 2018; Freiman et al. 2019).

An approach relying on the tie of horizons to linear magnetic anomalies in the Amundsen Basin has been applied for the Cenozoic interval of the section (Freiman et al. 2019). This method is based on the hypothesis of the spreading of the oceanic crust: The age of the horizon is considered equal to that of an anomaly at whose level the horizon is pinching out. The main reference Cenozoic horizons in the entire Arctic region were dated according to this assumption. The HASR Horizon (High Amplitude Seismic Reflectors) is one of these horizons. It is reliably correlatable with magnetic anomaly 21 no (45.724 Ma) (Freiman et al. 2019).

In their recent work, Rosneft geoscientists have applied an integrated approach comprising sequence stratigraphy, the method of geologic analogies, and the tie to wells Popcorn-1 and Ayon-1 (for the Cenozoic interval of the section) (Skaryatin et al. 2020, 2021).

A high level of uncertainty associated with the stratigraphic framework in the region creates significant diversity in geologic models of the sedimentary cover within the Russian sector of the Eastern Arctic and therefore different assessments of the territory's hydrocarbon potential. The geologic age of the pre-Aptian section remains the most debated issue.

After reviewing present day concepts of sedimentary stratigraphic architecture, we identified the following regional unconformities reflected by seismic data, which are agreeable with most geologic models: the Middle Brookian Unconformity (MBU) associated with the base of Cenozoic sediments, the Intra-Eocene Unconformity (InEoU) or High Amplitude Seismic Reflectors (HASR), two unconformities in the upper part of the Oligocene-Rupelian-Chattian unconformity or Erosional Surface (ES) and Aquitanian transgressive surface (Aq1) (Freiman et al. 2019; Skaryatin et al. 2020, 2021).

It is generally accepted that the MBU Horizon relates to the lower boundary of Cenozoic sediments. The unconformity corresponds to the orogenic event and the phase of uplifting recognized for the Brooks Range in Northern Alaska (Bird and Houseknecht 2011; Houseknecht 2019b,a; Kumar et al. 2011).

InEoU (Skaryatin et al. 2020, 2021) or HASR (Freiman et al. 2019) — the horizon marks the stage of a large-scale sea transgression in the region. The transgression was induced by the completion of rifting in the Makarov-Podvodnikov Basin and the onset of long-lived post-rift subsidence that affected the northern margin of the East Siberian shelf. Global warming that commenced in the Thanetian age and attained maximum expression during the Early Eocene (PETM-Paleocene-Eocene Thermal Maximum) and the connection established between the Chukchi and West
Siberian Seas could have also influenced the further expansion of the paleobasin's area (Skaryatin et al. 2020, 2021).

The next prominent stage of flooding is associated with the Chattian-Aquitanian transgression (Aq1), as indicated by the presence of marine deposits of the Ust'-Omolon Formation in well Ayon-1 (Skaryatin et al. 2020, 2021). It was preceded by the Rupelian-Chattian hiatus associated with the ES unconformity (Freiman et al. 2019), erosion, and cooling (Oi-1).

In light of the above, the considered Cenozoic interval comprises Paleogene-Quaternary deposits that can be split into the following three main complexes: Paleocene-Eocene, Eocene-Oligocene, and Miocene-Quaternary. According to Skaryatin et al. (2020, 2021), the upper complex can be further divided into the Lower-Middle Miocene, Middle-Upper Miocene, and Pliocene-Quaternary subcomplexes separated by the Intra-Miocene (InMio) and Middle-Neogene Unit (mNU) boundaries.

The prograding wedge reaches a maximum thickness of $3-3.5 \mathrm{~km}$ within the study area.

\section{Material and methods}

The work was completed in two stages (Fig. 2). The first stage involved regional-scale modeling. The evolution of sedimentary basins underlying the Laptev, East Siberian, and Chukchi Seas was reconstructed using numerical basin modeling on the structural framework at a scale of 1:5,000,000 produced by VSEGEI in 2014. The structural model comprises the following five surfaces: the base of the sedimentary cover, the pre-Aptian unconformity, the base of the Cenozoic, the near-Top Oligocene unconformity, and the base of Quaternary deposits.

The tectonic model developed by Equinor geoscientists in 2018 provided a basis for basin analysis. It spans from the Triassic to Paleogene inclusive and honors plate tectonic reconstructions based on the concept of the successive three-stage opening of the Arctic: the Canadian Basin, Podvodnikov Basin, and Eurasian Basin. These tectonic events were taking place as the Anyui Ocean was gradually closing (Somme et al. 2018).

In the absence of drilling data from the Eastern Arctic offshore areas, predictions about the material composition of deposits making up the sedimentary cover rest solely on paleogeographic reconstructions and are largely hypothetical. No lithofacies maps were conducted due to regional-scale modeling, and identical lithology was assigned to sedimentary complexes in the model. The lithology represented a mixture made from equal amounts of clay and sandstone. The mentioned considerable uncertainty about the material composition of deposits 
Fig. 2 Stratigraphic extent of regional and detailed basin and petroleum system models

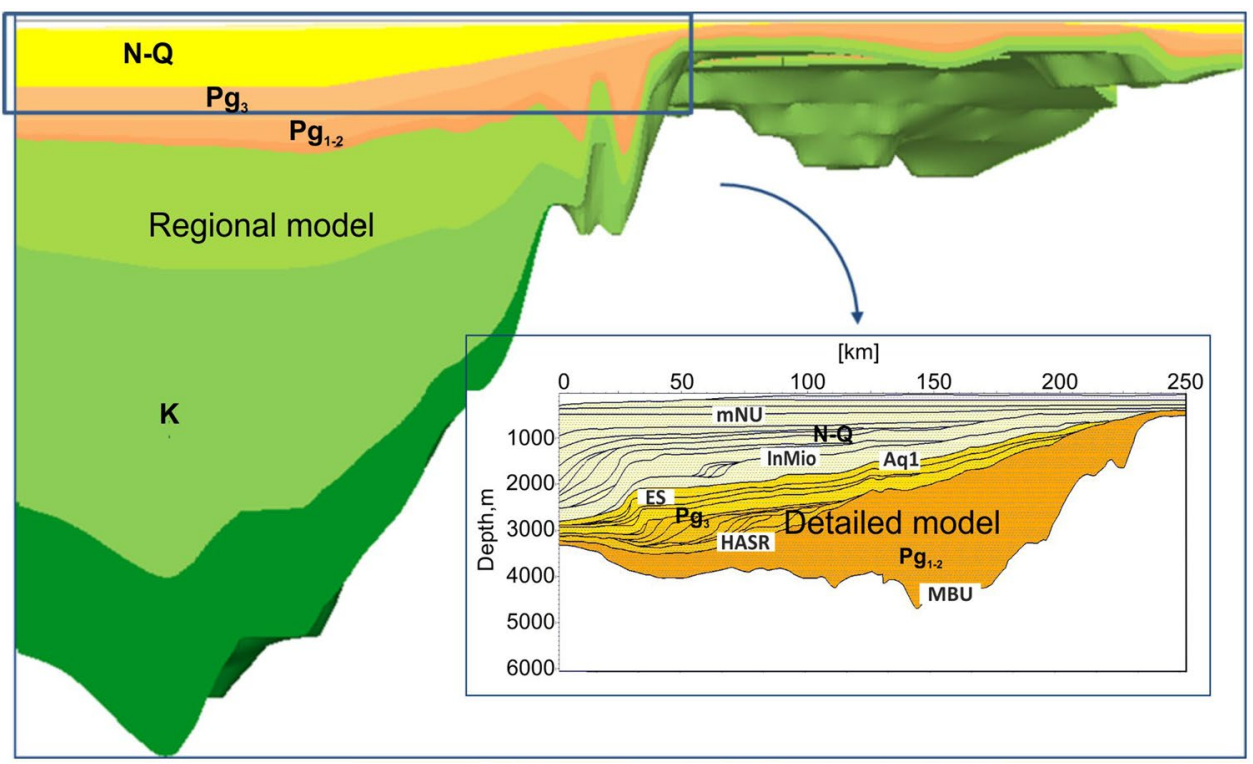

also makes it impossible to map essential elements of petroleum systems. Still, the analysis of paleogeographic conditions under which the deposits were accumulated enables us to infer their presence throughout all major complexes of the sedimentary cover. Given these considerations, hypothetical petroleum systems were incorporated in the model at the base of each complex. Two versions of computations were performed, with different kerogen types of source rocks corresponding to marine and terrestrial organic matter.

The following boundary conditions were taken into account during the basin modeling process: changes in the depth of paleobasins throughout their evolution, and temperature on the floor surface. The bathymetry of paleobasins was evaluated using regional paleogeographic maps. The automatic trend of $74^{\circ}$ North Latitude supported by the PetroMod software was used to calculate the temperature at the surface of the paleobasins' floor.

A total of six heat flow measurements are available within the studied area. All points are located in the Laptev Sea and are confined to the rift's shoulders. The obtained estimates are high, varying from 73 to $100 \mathrm{~mW} /$ $\mathrm{m}^{2}$, which is equivalent to a 'young' rift and is consistent with the hypothesis that the origin of the basin was riftdriven. On Lyakhovskiy Island (in the East Siberian Sea), heat flow estimates measured in the well amount to 50 $\mathrm{mW} / \mathrm{m}^{2}$, which is a typical value for plates. A schematic map showing heat flow distribution in the basins on the Russian part of the Eastern Arctic was prepared and used for modeling purposes. The map draws upon the information above and specific aspects of basins tectonics.

The second stage involved applying a scalable modeling technique and producing detailed models aim to assess the hydrocarbon potential of the Cenozoic interval, which had never been studied before in this respect. Since no 3D seismic data have been acquired within the territory of interest, several depth seismic lines were selected for detailed modeling purposes (Fig. 1). Their interpretation was done using the SAI technology (Gorbunov and Lavrenova 2018).

\section{Results and discussion}

The results produced by regional modeling have shown that the key factor controlling the evolution and hydrocarbon potential of petroleum systems in the Russian Eastern Arctic is the rate of basin subsidence and thickness of accumulated complexes of overburden rocks. Three hypothetical Paleocene petroleum systems were distinguished in the lower part of the Paleogene. They correspond to the major basins, i.e., the Laptev Sea, East Siberian and North Chukchi petroleum systems. Kerogen quality is an important factor controlling the type of fluid in expected accumulations of the examined petroleum systems. For example, the presence of marine organic matter in source rocks determines the predominance of liquid hydrocarbons. The Laptev Sea petroleum system is an exception, where because of higher heat flow values the fluid type is mostly controlled by the organic matter maturity and less its type (Fig. 3). Hydrocarbon accumulations are predicted in anticline traps that formed during the periods of tectonic activity in the region. One petroleum system identified in the lower part of the Neogene complex is located in the Laptev Sea. Judging from the findings of regional modeling, the processes of hydrocarbon expulsion from a potential source rock at the base 
A

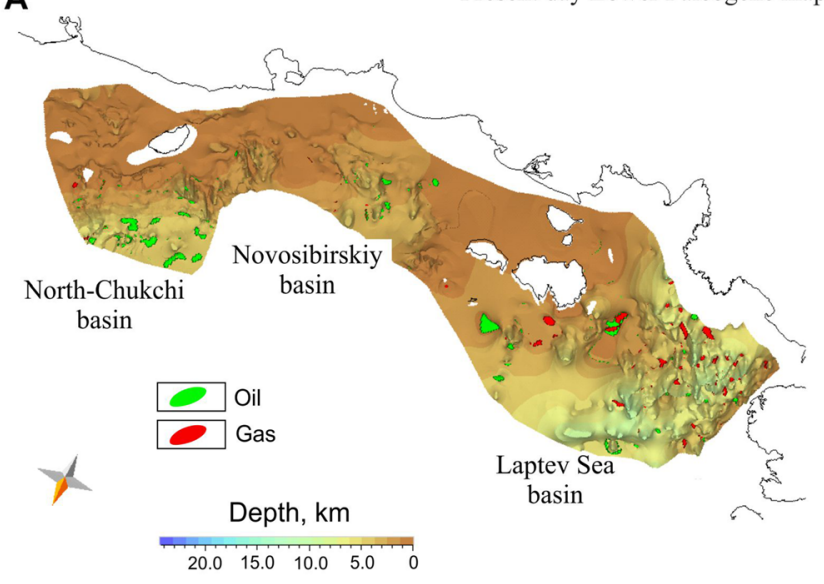

B

Present day Lower Paleogene map

Fig. 3 Results of 3D modeling, showing location of expected (modeled) hydrocarbon accumulations in Lower Paleogene deposits a with II type kerogen, $\mathbf{b}$ with III type kerogen

of the Neogene in the North Chukchi Basin have not yet commenced. Due to the limitations imposed by the regional model's simplified structural framework, the clinoform part of the Cenozoic section has not been properly studied, and its hydrocarbon potential remains underestimated. These problems were solved by a detailed modeling approach. The obtained results are shown below through the example of line ES10Z23_m (Fig. 1).

A total of 35 key reflecting boundaries were identified upon examining "Stratigraphic Cubes" of seismic sections with a view to building the structural framework (Fig. 4a). The boundaries are associated with important geologic events that determine particular aspects of the evolution undergone by the considered interval of the sedimentary cover and changes in depositional trends (depositional environments). These boundaries split the section into isolated sedimentary bodies, which group together into several sizeable sequences (units).

Lying at the base of the clinoform complex is the Lower Eocene unit (1) (Fig. 4b). After a period of maximum transgression during the Paleocene-Eocene transition, deposits were deposited in relatively deepwater environments, under global warming conditions (the PETM event). The transgressive settings were later replaced by a regressive one, possibly due to cooling, and Lower Eocene sediments suffered partial erosion. The Early Eocene regression is thought to reach a maximum during the Lutetian Age and led to the formation of a semi-enclosed freshwater basin in the Arctic, in which organic-rich Azolla layers were deposited (Skaryatin et al. 2020, 2021).

The prograding regressive wedge (2) onlaps against eroded unit (1), with an angular unconformity. The wedge is probably Eocene in age and was formed in coastal-marine settings. It is overlapped by sequence (3), whose deposits were laid down under predominantly transgressive conditions that culminated during the Oligocene-Miocene transition. Sediment deposition was supported by a strong source that provided large volumes of supplied sediment. Sediments were transported from southwest to northeast (Skaryatin et al. 2020, 2021).

During the Miocene, the direction of sediment supply changed to the northwestern (Skaryatin et al. 2020, 2021). The 2D model crosses the regressive Early Miocene unit (4) at an angle. In the latter half of the Miocene, a thick progradation-aggradation complex comprising (5-7) units deposited amid continued subsidence of the continental margin.

During the Pliocene-Quaternary, the East Siberian Sea shelf has continued its northeastward progradation. Only topset beds of the prograding wedge are identifiable on the seismic images, while foreset and bottomset beds are outside the detailed model's area.

For petroleum system modeling, we assigned source rock to sedimentary bodies inside transgressive units. In this case, we drew upon the analogy with the Tertiary complex in the Beaufort-Mackenzie Basin, which was deposited in similar environments (delta-plain, delta-front, prodelta, paralic). According to Morrell et al. (1995), four intervals in the lower part of the Tertiary clinoform can be regarded as potential source rock for coeval hydrocarbon accumulations within the basin. In terms of lithology, these are prodelta shales with a significant admixture of terrestrial organic matter. However, the rocks also contain oil-prone kerogen in the form of resinite, which is capable of generating petroleum hydrocarbons at low levels of organic matter maturity. Although TOC is rarely above $2 \%$ in these deposits, the ability of Tertiary clays to generate substantial volumes of petroleum hydrocarbons has been demonstrated through the example of the Amauligak field, where a biomarker analysis has confirmed

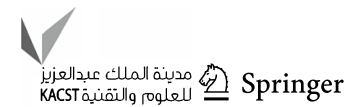



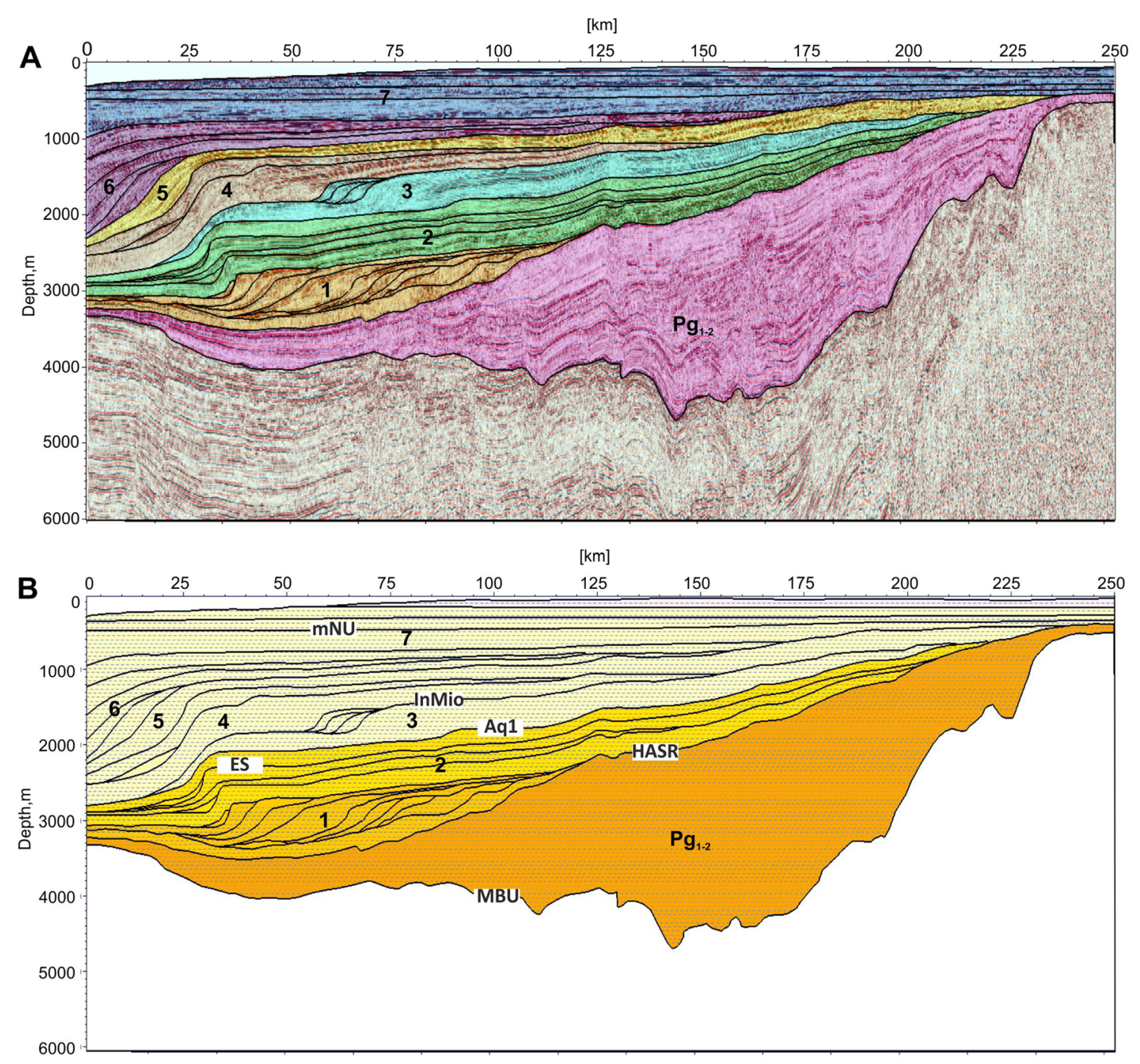

Fig. 4 Stratigraphic cube of seismic depth section (ES10Z23_m), showing a prominent Tertiary sedimentary units as well as 35 horizons, corresponded with significant geologic events and $\mathbf{b}$ geologic cross section with regional stratigraphic benchmark

a genetic relationship between oil accumulations and Tertiary source rock (Morrell et al. 1995).

Moreover, recent studies have shown that a Paleogene source rock is inferred to be the primary charge in the Kuvlum1 (Sagavanirktok reservoir) and Stinson1 (Canning and Franklinian basement reservoirs) discoveries on Alaska North Slope. Also, the oils from saturated outcrops and one seep along the Arctic National Wildlife Refuge (ANWR) coast yield biomarker evidence for a Tertiary source rock (Botterell et al. 2021). Although oil source rock properties of the Paleogene interval have not been studied in Alaska, the Canning Fm clays are assumed to be the most probable source rock. Usually, this is a transgressive succession deposited during significant landward retreat of the shoreline (Botterell et al. 2021).
Given these considerations and taking into account specific aspects of clinoform complex formation, we distinguished five potential source rocks in the Eocene, Oligocene, and Miocene deposits of the Cenozoic clinoform within the study area. Based on the expected depositional trends, the mixed type of organic matter for the Oligocene and Miocene source rocks, and marine-for the Early Eocene source rocks were assumed. Initial TOC for all source rocks was taken equal to $2 \%$.

Reservoirs are expected in the topset beds of regressive units and distal fans at the bottom of the prograding sedimentary wedge, providing that they were visible on seismic.

Figure 5 illustrates the calculated vitrinite reflectance of the examined source rocks. None of the modeled source rocks overcome the "oil window." Their maturity is 


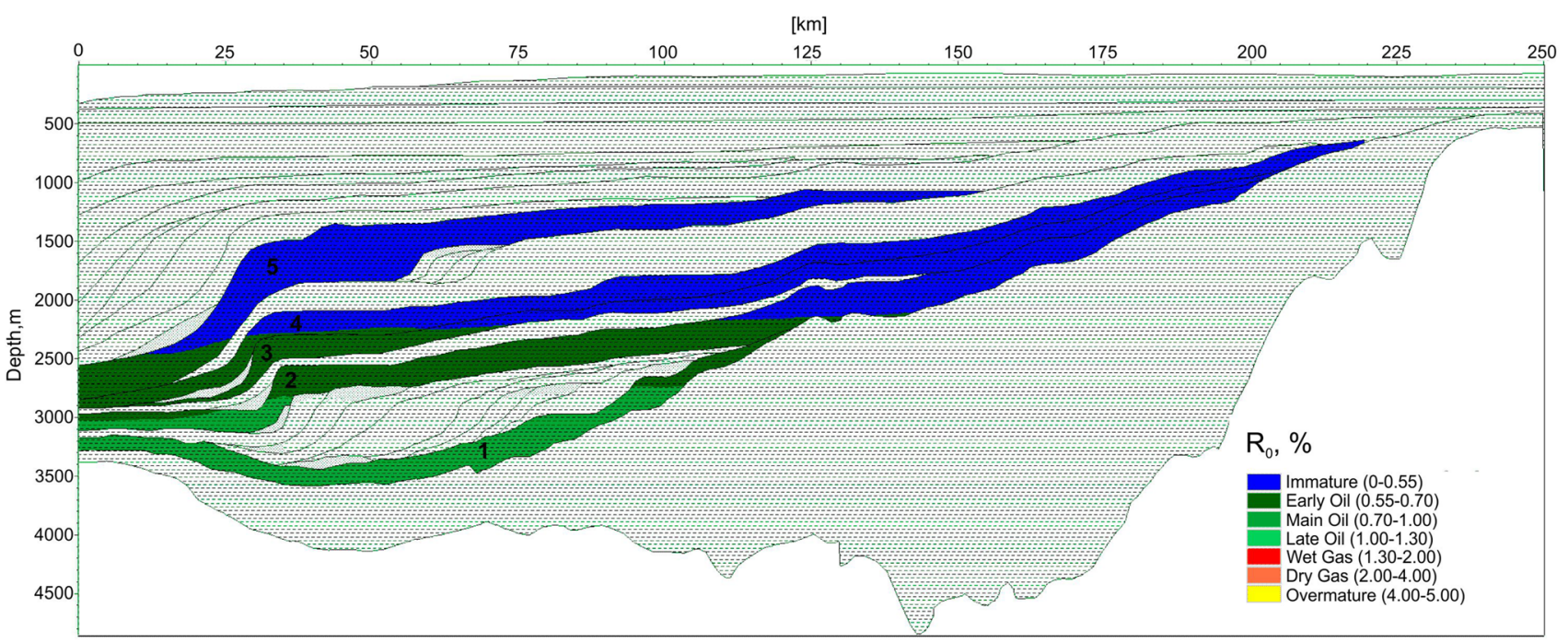

Fig. 5 Present day vitrinite reflection (R0) map of Tertiary transgressive bed sets supposed to be source rock indicating minor maturity of Upper Oligocene (4) and Lower Miocene units (5)

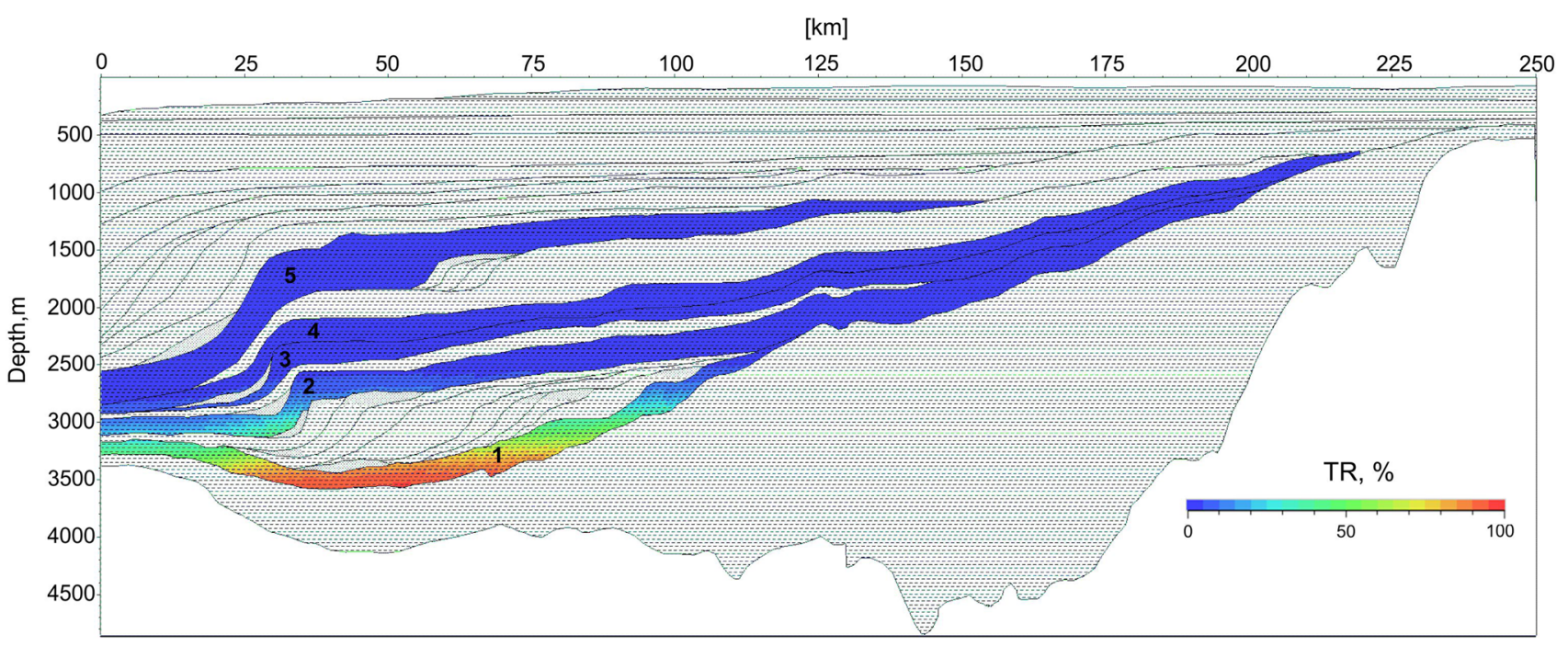

Fig. 6 Present day Transformation Ratio map of Tertiary supposed to be source rock. Calculated fractional conversion of organic matter indicating significant hydrocarbon generation only from Lower Eocene (1) and Lower Oligocene (2) units

distributed in an irregular manner across the section and is controlled by the thickness of overburden strata.

The highest maturity for source rocks $3,4,5$ is within the "early oil." In addition, the TR (Transformation Ratio) is extremely low in the most mature part of these source rocks (Fig. 6), preventing regarding them as an important hydrocarbon source for prospective Cenozoic targets. This is consistent with the modest generation and expulsion potential exhibited by these source rocks.

Source rocks 1 and 2 (in the most subsided part of the sedimentary cover) exhibit maximum maturity (Figs. 5, 6). Source rock 1 is mostly exhausted. The TR of the source rock 2 does not exceed 50\%. A review of hydrocarbon generation and expulsion charts of assumed Tertiary source rocks shows that the main hydrocarbon contributor for Cenozoic deposits is Eocene-aged source rock 1, also Lower Oligocene source rock 2, but to a far lesser degree. The contribution from others is negligible (Fig. 7).

According to the numeric modeling, hydrocarbon generation in the Lower Eocene source rock started about 15 mya ago and about 12 mya ago hydrocarbons began to expel. Source rock passed the critical moment not until 5 mya ago (in its most subsided part) (Figs. 7, 8). 


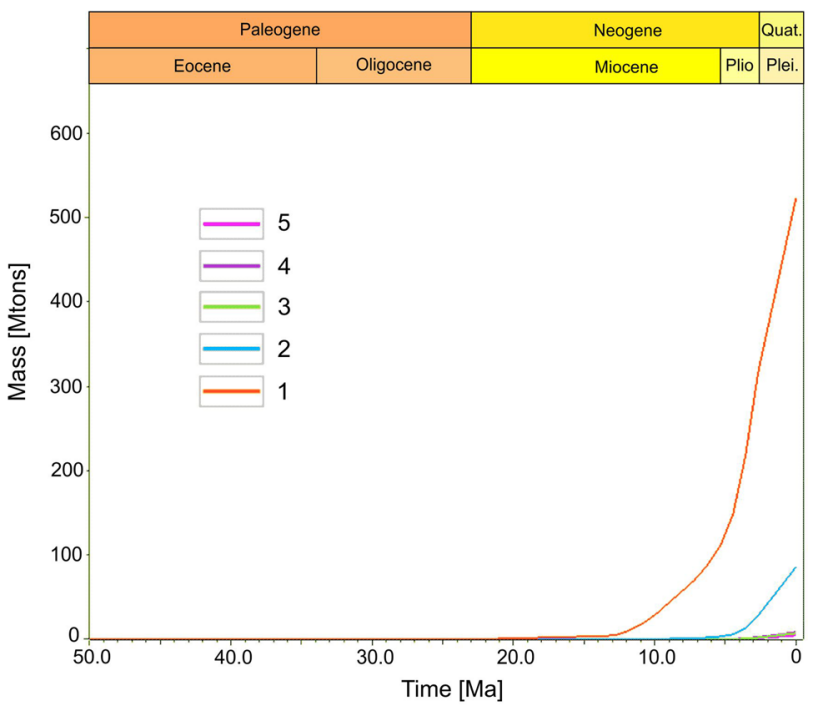

Fig. 7 Hydrocarbon generation chart of Tertiary supposed to be source rock

First accumulations in Cenozoic deposits are expected to appear about 12 mya ago. All stratigraphic traps had already been formed by this time. According to the obtained modeling results, all of them can bear hydrocarbons by now (Fig. 9). According to our prediction, the traps contain liquid hydrocarbons with dissolved gas. The accumulations in prospective targets occurring at shallow depths $(2 \mathrm{~km}$ down the sea bottom) may have a gas cap.

The results produced by the modeling attend to the presence of an active petroleum system in the clinoform part of Cenozoic deposits. But it is still impossible to quantify its hydrocarbon prospects in so far. The East Siberian Sea poorly studied. Hence, there are unanswered questions about the economic feasibility of further geologic studies into this region.

However, a certain understanding of the possible outlook can be gained by reviewing the information about the upper Brookian deposits of the Nanushuk and Torok Formations, which are Upper Cretaceous progradational clastic deposits in the Colville Basin of Alaska (Houseknecht et al. 2001; Houseknecht 2003) as well as Tertiary sediments of the Beaufort-Mackenzie Basin, which are of clinoform structure. These targets have proven oil and gas discoveries and have been fairly well studied.

The current resource assessment of the hydrocarbon potential of Brookian clinoform deposits in North Alaska (NPR-A and the North Slope) suggests their substantial hydrocarbon potential varying from 0.5 to 6 bln toe (about 2 bln toe on average) (Houseknecht 2017; Houseknecht et al. 2020). Recent major discoveries in stratigraphic traps in this prospective complex (Willow-42 $\mathrm{mln}$ tons of oil, Smith Bay and Pikka-Horseshoe-more than $140 \mathrm{mln}$ tons of oil each) have provided an incentive for its vigorous development. However, as is often the case, new data have spawned more questions than answers regarding an understanding of regularities behind the lateral distribution of accumulations, reservoir quality, etc. (Bhattacharya and Verma 2020). Among the wells drilled in 2019-2020, some showed promising results (such as the Stirrup 1, Mitquq 1, and Tinmiaq wells), whereas others showed mixed results (such as Charlie 1, and Winx 1) (Verma and Bhattacharya 2020).

According to the current assessment, the probability of discovering large oil and gas fields in lithologic traps in the Nanushuk and Torok Formations is not high. The most probable pool size is about $10 \mathrm{mln}$ tons within the NPR-A and

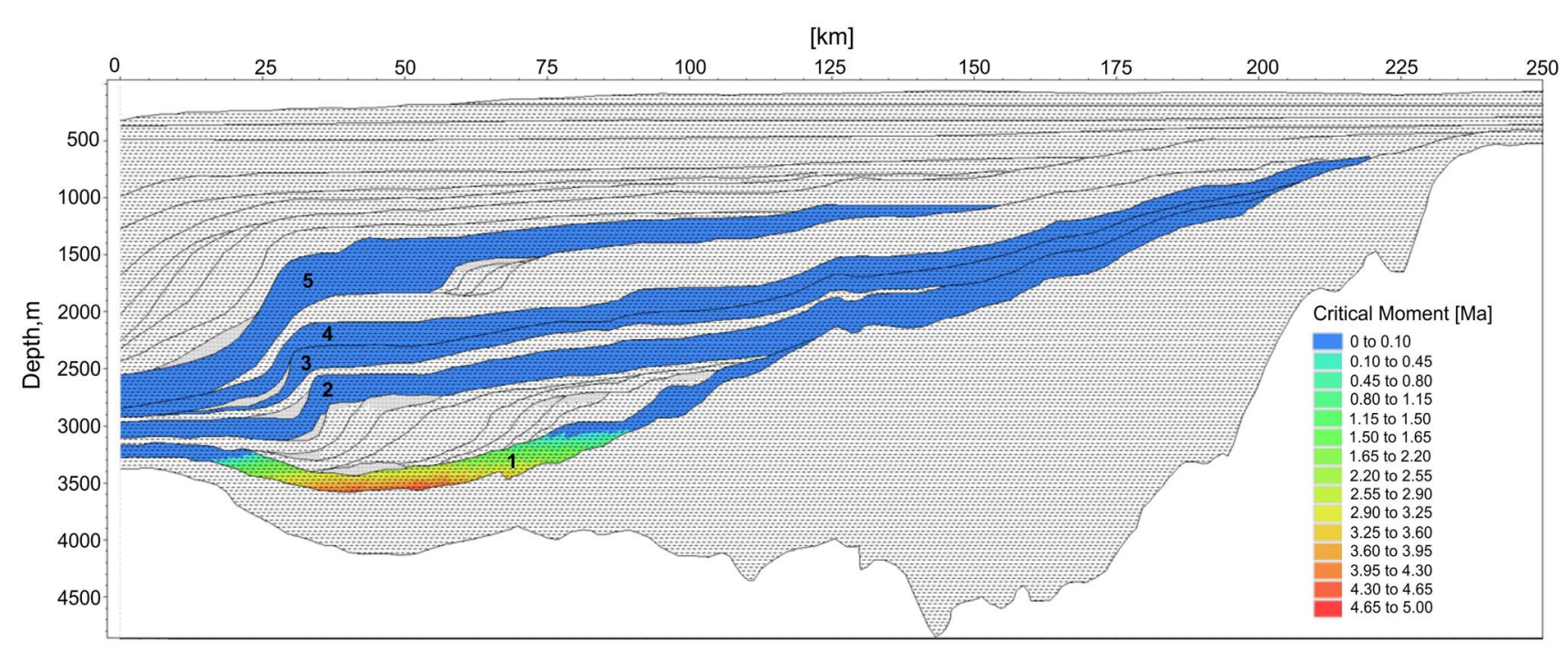

Fig. 8 Critical moment map of Tertiary supposed to be source rock 


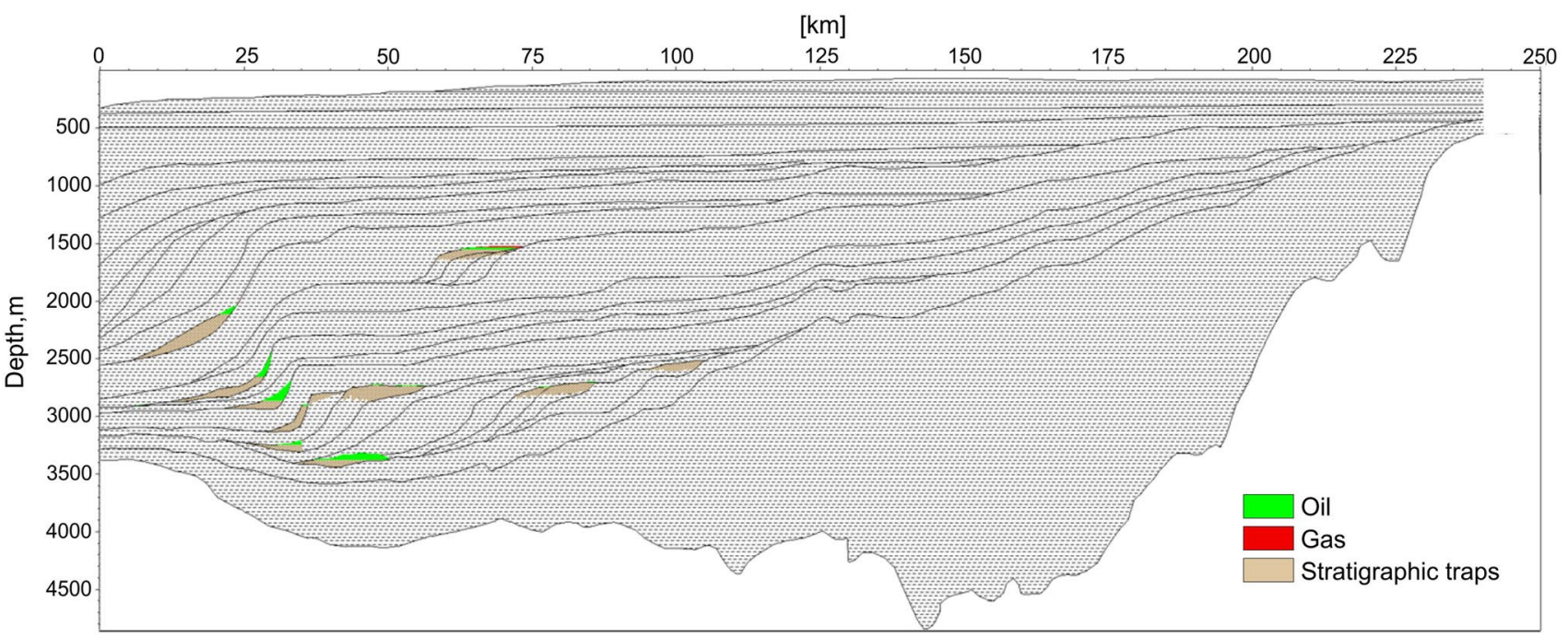

Fig. 9 Simulated hydrocarbon saturation of Tertiary stratigraphic traps

5 mln tons on the North Slope (Houseknecht 2017; Houseknecht et al. 2020). The situation is more reassuring in the Beaufort-Mackenzie Basin, where the structural factor plays a significant role and combination (structural-lithologic) traps are well represented. Half of the discovered gas fields contain accumulations estimated at $2.8 \mathrm{BCM}$ and more. On average, onshore and offshore oil fields contain up to $14 \mathrm{mln}$ tons and up to $70 \mathrm{mln}$ tons of oil, respectively (Morrell et al. 1995). Taking into account this information, prospective targets in Tertiary clinoform deposits in the East Siberian Sea may be of interest as either a cluster or as satellites during the exploration of large anticlinal features in the underlying deposits of the sedimentary cover.

\section{Conclusions}

The results obtained from basin analysis and numerical modeling indicate the possibility that an active petroleum system may exist in the Cenozoic clinoform wedge of the East Siberian Sea.

The most probable source for potential lithologic traps is Lower Eocene deposits occurring at the base of the prograding wedge. It is assumed, they were formed under favorable conditions for organic matter accumulation and may contain Type II kerogen. The distal parts of transgressive units in the Oligocene interval of the sedimentary cover may constitute an additional hydrocarbon source if they are sufficiently mature. These potential source rocks may contain mixed Type II-III kerogen.

The outlook for the clinoform complex largely depends on the source rock maturity, i.e., higher prospects should be expected in areas where the prograding wedge has maximum thickness.

Predominantly oil accumulations with dissolved gas are expected, in line with the predicted kerogen type and organic matter maturity obtained from modeling. All prospective stratigraphic traps (topset beds and bottomset beds) may contain hydrocarbons.

Considering all factors (reservoir quality prediction, proximity to a hydrocarbon kitchen, timing), the Eocene-Oligocene part of the sedimentary section appears to offer the greatest promise within the study area. Here, hydrocarbon accumulations may be expected at a depth of $2.5-3.5 \mathrm{~km}$ below sea bottom.

Funding The reported study was funded by RFBR, project number 20-35-70062.

Availability of data and material Not applicable.

Code availability Not applicable.

\section{Declarations}

Conflict of interest On behalf of all the co-authors, the corresponding author states that there is no conflict of interest.

Open Access This article is licensed under a Creative Commons Attribution 4.0 International License, which permits use, sharing, adaptation, distribution and reproduction in any medium or format, as long as you give appropriate credit to the original author(s) and the source, provide a link to the Creative Commons licence, and indicate if changes were made. The images or other third party material in this article are included in the article's Creative Commons licence, unless indicated otherwise in a credit line to the material. If material is not included in the article's Creative Commons licence and your intended use is not

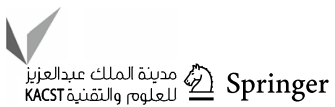


permitted by statutory regulation or exceeds the permitted use, you will need to obtain permission directly from the copyright holder. To view a copy of this licence, visit http://creativecommons.org/licenses/by/4.0/.

\section{References}

Bhattacharya S, Verma S (2020) Seismic attribute and petrophysicsassisted interpretation of the Nanushuk and Torok Formations on the North Slope. Alaska Interpretation 8(2):1-18. https://doi.org/ 10.1190/INT-2019-0112.1

Bird KJ, Houseknecht DW (2011) Geology and petroleum potential of the Arctic Alaska petroleum province, chap. 32 of Spencer. In: Embry AM, Gautier DL, Stoupakova AV, Sorensen K (eds) Arctic petroleum geology: The Geological Society of London, Memoir 35: 485-499. https://doi.org/10.1144/M35.32

Botterell PJ, Houseknecht DW, Lillis PG et al (2021) Geochemical advances in Arctic Alaska oil typing-North Slope oil correlation and charge history. Mar Pet Geol 127:1-24. https://doi.org/10. 1016/j.marpetgeo.2020.104878

Chmielowski J, Pikka-Horseshoe, Willow, Smith Bay (2018) Unraveling Three New Discoveries with Publicly Available Data. https:// dog.dnr.alaska.gov/documents/resourceevaluation/01_ags_lunch eon_presentation_04-24-18.pdf

Freiman SI, Nikishin AM, Petrov EI (2019) Cenozoic Clinoform complexes and the Geological History of the North Chukchi Basin (Chuckchi Sea, Arctic). Mosc Univ Geol Bull 74(5):441-449. https://doi.org/10.3103/S0145875219050053

Gorbunov A., Lavrenova E (2018) SAI-advanced solution to geologic objectives. Preprint. https://doi.org/10.13140/RG.2.2.30054. 47689.

Houseknecht DW (2017) National and global petroleum assessment assessment of undiscovered oil and gas resources in the Cretaceous Nanushuk and Torok formations, Alaska North Slope, and summary of resource potential of the National Petroleum Reserve in Alaska. USGS Science or a Changing World. https://doi.org/ $10.3133 /$ fs 20173088

Houseknecht DW (2019a) Petroleum systems framework of significant new oil discoveries in a giant Cretaceous (Aptian-Cenomanian) clinothem in Arctic Alaska. AAPG Bull 103(3):619-652. https:// doi.org/10.1306/08151817281

Houseknecht DW, Christopher J, Schenk (2001) Depositional sequences and facies in the Torok formation, national petroleum reserve-Alaska (NPRA). USGS Science or a Changing World. https://doi.org/10.2110/cor.01.01.0179

Houseknecht DW, Katherine J, Whidden et al (2020) Assessment of Undiscovered Oil and Gas Resources in the Central North Slope of Alaska. USGS Science or a Changing World. https://doi.org/ $10.3133 /$ fs 20203001

Houseknecht DW (2003) Brookian stratigraphic plays in the National Petroleum Reserve, Alaska (NPRA). USGS science or a changing world. https://doi.org/10.3133/ofr0339

Houseknecht DW (2019) Evolution of the Arctic Alaska sedimentary basin, chap. 18 of Miall. In: A.D. (ed) The sedimentary basins of the United States and Canada, 2nd edn. Elsevier, Amsterdam, pp 719-745. https://doi.org/10.1016/B978-0-444-63895-3.00018-8

Ilhan I, Coakley B, Houseknecht DW (2018) Meso-Cenozoic evolution of the Chukchi Shelf and North Chukchi Basin. Arctic Ocean Mar Petrol Geol, 95. https://doi.org/10.1016/j.marpetgeo.2018.04.014

Kerimov VY, Mustaev RN, Osipov AV (2018b) Peculiarities of hydrocarbon generation at great depths in the crust. Dokl Earth Sci 483(1):1413-1417. https://doi.org/10.1134/S1028334X18110193

Kerimov V, Rachinsky M, Mustaev R, Serikova U (2018c) Geothermal conditions of hydrocarbon formation in the South Caspian basin. Iran J Earth Sci 10(1):78-89
Kerimov VY, Leonov MG, Osipov AV, Mustaev RN, Hai VN (2019) Hydrocarbons in the basement of the South China Sea (Vietnam) shelf and structural-Tectonic model of their formation. Geotectonics 53(1):42-59. https://doi.org/10.1134/S0016852119010035

Kerimov VYu, Gordadze GN, Mustaev RN, Bondarev AV (2018) Formation conditions of hydrocarbon systems on the Sakhalin shelf of the sea of okhotsk based on the geochemical studies and modeling. Oriental J Chem 34(2):934-947. https://doi.org/10.13005/ ojc/340243

Kumar N, Emmet PA, Granath J (2011) Chapter 33: Stratigraphic and tectonic framework of the US Chukchi Shelf: exploration insights from a new regional deep-seismic reflection survey. Geol Soc Lond Memoirs 35(1):501-508. https://doi.org/10.1144/M35.33

Lavrenova EA, Burguto AG, Gorbunov AA, Kerimov VYu, Mustaev RN (2019) Comparative analysis of East Arctic Basins evolution. Geomodel. https://doi.org/10.3997/2214-4609.201950039

Morrell GR, Fortier M, Price PR, Polt R (1995) Petroleum exploration in Northern Canada. A Guide to Oil and Gas Exploration and Potential. Northern Oil and Gas Directorate Indian and Northern Affairs Canada https://www.aadnc-aandc.gc.ca/DAM/DAM-INTER-HQ/ STAGING/texte-text/nog_pubs_penc_1324579829739_eng.pdf

Mustaev RN, Kerimov VY, Shilov GY, Dmitrievsky SS (2016) Modeling of thermobaric conditions formation of the shale hydrocarbon accumulations in low-permeability reservoirs khadum formation ciscaucasia. Geomodel 2016 - th Science and Applied Research Conference on Oil and Gas Geological Exploration and Development. https://doi.org/10.3997/2214-4609.201602185

O'Sullivan PB, Blythe AE, Murphy JM (1997) Late Mesozoic and Cenozoic thermo tectonic evolution of the central Brooks Range and adjacent North Slope foreland basin, Alaska: including fission track results from the Trans-Alaska Crustal Transect (TACT). J Geophys Res 102(B9):821-845. https://doi.org/10.1029/96JB03411

Patrunoa S, Helland-Hansenb W (2018) Clinoforms and clinoform systems: review and dynamic classification scheme for shorelines, subaqueous deltas, shelf edges and continental margins. Earth Sci Rev 185:202-233. https://doi.org/10.1016/j.earscirev.2018.05.016

Skaryatin MV, Batalova AA, Borodulin AA, Bulgakova EA, Malyshev NA, Mazaeva IV, Moiseeva RKh, Obmetko VV, Stavitskaya VN, Verzhbitskiy VE, Vinnikovskaya EV, Zaytseva SA (2020) Spatial offlap break trajectory analysis for stratigraphic framework building of the North Chukchi trough sedimentary cover. Neftyanoye Khoziastvo 11:20-26. https://doi.org/10.24887/ 0028-2448-2020-11-20-26

Skaryatin MV, Batalova AA, Borodulin AA, Bulgakova EA, Malyshev NA, Mazaeva IV, Moiseeva RKh, Obmetko VV, Stavitskaya VN, Verzhbitskiy VE, Vinnikovskaya EV, Zaytseva SA (2021) Application of spatial offlap break trajectory analysis of the North Chukchi Trough clinoforms for hydrocarbon evaluation. Neftyanoye Khoziastvo 02: 40-45. https://doi.org/10.24887/ 0028-2448-2021-2-40-45

Somme TO, Dore AG, Lundin ER, Torudbakken BO (2018) Triassic paleogeography of the Arctic: implications for sediment routing and basin fill. AAPG Bull 102(12):2481-2517. https://doi.org/10. 1306/05111817254

Verma S, Bhattacharya S (2020) A Tale of Two Conventional Reservoirs: Nanushuk and Torok on the North Slope, Alaska. AAPG Explorer. https://doi.org/10.1306/42551. https://doi.org/10.1306/ 13311444H43477

Publisher's Note Springer Nature remains neutral with regard to jurisdictional claims in published maps and institutional affiliations. 